\title{
Influence of Pedagogic and Professional Competence towards Social Competence and Student Personality at Teacher Professional Education program, Universitas Negeri Padang
}

\author{
Armida. S1, Yulna Dewita Hia ${ }^{2}$, Ivan Reynadi ${ }^{3}$ \\ 1 Universitas Negeri Padang, Padang, Indonesia, $\triangle$ mimiasriel@gmail.com \\ ${ }^{2}$ STKIP PGRI, Padang, Indonesia, $\square$ yulnadewitahia@gmail.com \\ ${ }^{3}$ Universitas Negeri Padang, Padang, Indonesia, $\triangle$ ivanreynaldi@gmail.com
}

\begin{abstract}
This research aims to reveal the impact of pedagogic and professional competence on social competence and personality of PPG students SM-3T Universitas Negeri Padang. This type of research is descriptive and associative. Total respondents in this study were 164 people. The data analysis technique is a descriptive analysis and inductive analysis, classical assumption test: normality test, multicollinearity test, and hypothesis test using test $\mathrm{F}$ and $\mathrm{T}$ test, using the Statistical Product and Service Solution (SPSS) program. The results showed that (1) there was a significant influence between pedagogic competencies to the improvement of social and personality competencies, with a value of $\mathrm{T}$ count of $2.132>\mathrm{T}$ table 1.960 (2) There is no significant influence from Professional competence towards improving social and personality competencies, with a value of $\mathrm{T}$ calculated $0.290>\mathrm{T}$ table 1.960 and (3) there is a significant influence between pedagogic and professional competence towards improving social competence And personality of PPG students SM-3T generation IV of Universitas Negeri Padang with a value F count of $3.157>$ F table 1.890. Based on the coefficient determinant (R2) of pedagogic competence and professional competence together contributes to the increase of social and personality competence by $3.8 \%$.
\end{abstract}

Keywords: pedagogic competence, professional competence, social competence, and personality competence

\section{Introduction}

Universitas negeri padang has been implementing Pendidikan Profesi Guru-Sarjana Mendidik di daerah Terluar, Terdepan dan Tertinggal (PPG-SM3T) until the 6th generation. PPG is a higher education after undergraduate education program that prepares students to have jobs with special skills requirements in becoming a teacher and sending teachers to various parts of the country. The number of PPG SM-3T participants in the State University of Padang each lift varies, this is due to the number of participants who register and pass the administration and interviews each year also varies. During the lecture they were placed in dormitories. Which aims to develop the personality of PPG SM-3T, namely: (1) The development of sports and Health, (2) The development of Mental Spirituality, (3) Coaching National Insight, (4) Talent Coaching, (5) Community devotion. A small number of students will certainly affect the learning model conducted in the human resources and facilities as well as the means used that comes down to learning outcomes in this case the value of UTN.

During the UNP implementing PPG SM3T the highest-boarding learning outcomes (UTN) achieved by PPG student SM3T at the national level of 3 years 2015, is ranked 1, 2 and 4 of the highest in Indonesia to be achieved by the study Program of Economics Education and Student participants PPG SM-3T pass $100 \%$ in UTN, but in the next year of force 4 to 6 levels of disgraduate in UTN increased, even almost 25\% of PPG participants SM3T implemented UNP has not been declared to pass when UTN. This, indicating the value of pedagogic and professional competence is also low, but whether the competence of 
pedagogic and low professional also indicates social and personality competence is also low?. Based on this research study is the extent of the influence of pedagogic competence and professional student PPG SM-3T to the value of social and personality competence in the State University of Padang

\section{Methods}

Research conducted is a descriptive research associative. Descriptive research is a study describing, analyzing, solving problems researched by collecting data, describing and interpreting data based on the facts. Respondents in this study as much as 164 people. The instrument in the study was a closed-form poll, which was given to the respondents in the partners with the following indicators:

Table 1 Research Indicators

\begin{tabular}{|c|c|c|c|c|}
\hline \multirow[b]{2}{*}{ No. } & \multirow[b]{2}{*}{ Variabel } & \multirow[b]{2}{*}{ Indicator } & \multicolumn{2}{|c|}{ No. Item } \\
\hline & & & $(+)$ & $(-)$ \\
\hline \multirow[t]{10}{*}{1} & \multirow{10}{*}{$\begin{array}{l}\text { competence } \\
\text { Pedagogic }\end{array}$} & 1. Mastering learners ' characterisitics. & - & 1 \\
\hline & & $\begin{array}{l}\text { 2. Mastering the theories and principles of } \\
\text { learning }\end{array}$ & 2 & - \\
\hline & & $\begin{array}{l}\text { 3. Develop the curriculum in accordance } \\
\text { with the areas }\end{array}$ & 3 & - \\
\hline & & 4. Conducting educational learning & 4 & - \\
\hline & & $\begin{array}{l}\text { 5. Utilizing information technology and } \\
\text { communication in learning }\end{array}$ & - & 5 \\
\hline & & $\begin{array}{l}\text { 6. Facilitate the development of potential } \\
\text { learners }\end{array}$ & - & 6 \\
\hline & & 7. Communicating effectively with learners & - & 7 \\
\hline & & $\begin{array}{l}\text { 8. Implement assessment and evaluation of } \\
\text { learning outcomes process. }\end{array}$ & 8 & - \\
\hline & & $\begin{array}{l}\text { 9. Utilize assessment results and evaluation } \\
\text { for learning. }\end{array}$ & 9 & - \\
\hline & & $\begin{array}{l}\text { 10. Take reflective action for improved } \\
\text { learning }\end{array}$ & - & 10 \\
\hline \multirow[t]{5}{*}{2} & & 1. Master the subject matter that can be. & - & 11 \\
\hline & & $\begin{array}{l}\text { 2. Mastering core competencies and basic } \\
\text { competencies of subjects. }\end{array}$ & - & 12 \\
\hline & & 3. Develop Creative learning materials & 13 & - \\
\hline & & $\begin{array}{l}\text { 4. Follow the progress of the age by learning } \\
\text { from various sources. }\end{array}$ & 14 & - \\
\hline & & $\begin{array}{l}\text { 5. Utilize information and communication } \\
\text { technology to communicate and develop } \\
\text { themselves. }\end{array}$ & 15 & - \\
\hline
\end{tabular}

Source: PLK Manual 2016

\section{Results and Discussion}

Based on the results of data processing through the hypothesis test obtained that the pedagogic competence and professional competence of the student PPG SM-3T jointly significantly affect the social competence and personality of PPG SM-3T students State University of Padang. The better the pedagogic 
competence and professional competence owned by PPG students SM-3T, the better the social and personality competencies that are owned by PPG students SM-3T.

Pedagogic competence contains the meaning of commitment to duty, science, and devotion. While the professionalism of teachers is that the teacher must have extensive knowledge and subject matter (field of study) to be taught and methodological mastery in the sense of having the right method and able to use it in the learning process Teaching (Arikunto, 1993). Pedagogic competence contributes to the professionalism of teachers, so that teachers have the ability to manage learning with the right methods, media and learning resources.

Armed with a good pedagogic competence, the professionalism of the teacher will be good. One of the professional components of the teacher is the ability to manage yourself to be a personal figure who can be a dowager for students and have a noble character.

Personality competence is the inherent ability of educators in a steady, stable, mature, wise, and authoritative example for the students, and the noble (Mulyasa, 2012:117). In the explanation of government regulation No 19 year 2005 on national standards of education mentioned that the personality competence of teachers is personality abilities that: (1) steady; (2) stable; (3) Adults; (4) expedient and wise; (5) authoritative; (6) Noble morality; (7) To be an example for learners and communities; (8) evaluate its own performance; and (9) develop themselves continually.

The professionalism of the teacher is that the teacher must have extensive knowledge and subject matter (field of study) to be taught as well as methodological mastery in the sense of having the right method and able to use it in the teaching and learning process (Arikunto,1993:239). To master the right method and knowledgeable of a teacher must have pedagogic competence. Pedagogic competence is the ability of teachers to manage learning, personality competence is the ability of teachers in speech and behave noble in carrying out its duties, and the professionalism of teachers is the ability of teachers in Perform tasks with professional and responsible so as to deliver learners live independently. To become a professional teacher, a teacher must have pedagogic competence and good personality competence.

From the results of the data processing obtained results for the simultaneous value of hypothetical significance is 0.045 . This indicates that the value of significance is less than 0.05 , hence the hypothesis is acceptable, and the F value counts by 3.157. This value is greater when compared to the F-value of the table 1.89. Based on an analysis of the regression equation obtained from multiple regression calculation results regarding the effect of the dependent variable $(\mathrm{Y})$ with independent variables $(\mathrm{X} 1, \mathrm{X} 2)$. While the coefficient of determinant (R2) is obtained at 0038 or $3.8 \%$.

This indicates that the variable contribution of pedagogic competence and professional competence in this research is $3.8 \%$. This means that if the pedagogic competence and professional competence together increase one unit, will contribute to the improvement of social competence and personality competency of PPG students SM-3T State University of Padang 3.8 \%.

Thus pedagogic competence and professional efficacy have a significant influence with social competence and personality. The higher the pedagogic competence and professional competence of one, the better also the social and personality competence owned by PPG students SM-3T. The results of this research in accordance with the opinion of Sanusi (1991) Teachers as professional educators have a good image in the community when it can show the community that it deserves to be role models or examples of the surrounding community. Based on the exposure of research results can be suggested that students of PPG SM-3T who have a high value of pedagogic competence and professional competence, also have good social and personality competence.

Pedagogic competence is the ability to manage learners ' learning that includes understanding of learners, learning planning and implementation, evaluation of learning outcomes, and development of learners to actualize of its potential (Mulyasa, 2012:75).A teacher has the ability to manage learning with the right methods, media and learning resources. Armed with a good pedagogic competence, the 
professionalism of the teacher will be good. To master the right method and knowledgeable of a teacher must have pedagogic competence.

Pedagogic competence contains the meaning of commitment to duty, science, and devotion while the professionalism of teachers, is that the teacher must have extensive knowledge and subject matter (field of study) to be taught and mastery Methodological in the sense of having the right method and able to use it in the process of teaching learning (Arikunto, 1993:239)

The professionalism of the teacher is that the teacher must have extensive knowledge and subject matter (field of study) to be taught as well as methodological mastery in the sense of having the right method and able to use it in the teaching and learning process (Arikunto, 1993:239). One of the professional components of the teacher is the ability to manage yourself to be a personal figure who can be a dowager for students and have a noble character.

Personality competence is the inherent ability of educators in a steady, stable, mature, wise, and authoritative example for the students, and the noble (Mulyasa, 2012:117). Further, the personality competence described in Permendiknas number 16 of 2007 includes the ability (1) to act in accordance with the national religious, legal, social, and cultural norms of Indonesia; (2) presenting itself as an honest, noble-worthy person, and an example for learners and society; (3) presenting itself as a steady, stable, mature, expedient, and authoritative person, (4) demonstrate the work ethic, high responsibility, pride of being a teacher, and self-confidence, (5) Uphold the teacher's profession ethics code.

In the explanation of government regulation No 19 year 2005 on national standards of education mentioned that the personality competence of teachers is personality abilities that: (1) steady; (2) stable; (3) Adults; (4) expedient and wise; (5) authoritative; (6) Noble morality; (7) To be an example for learners and communities; (8) evaluate its own performance; and (9) develop themselves continually.

Teachers must have a steady and stable personality. So: acting in accordance with the legal norm, acting in accordance with social norms, proud as educators, and having consistency in acting in accordance with the norm of personality teachers is very strong influence on his duties as an educator. The authority of the teacher is in her personality. It is difficult for teachers to educate learners to emulate and replicate their teachers so that what teachers say should be the same as their actions. The teacher means an imitated and drafted by the learners. In order to be appropriately imitated and made by learners, teachers must have high moral, and apply the values they have in action. As such, he will be a worthy person as an example. To improve the professionalism of educators, a teacher must work with a trust, responsibility, discipline as a teacher is an example for learners. Therefore, PPG student SM-3T University of Padang Negeri is expected to further improve pedagogic competence and professionalism competence through trainings, seminars and workshops and increase social and personality outcomes. In the form of interactions with pupils, parents, associates and communities in the form of social work activities, community visits and acting and behave in accordance with the legal and social norms that exist in the community. So teachers as professional educators have a good image in the community and deserve to be role models or examples of the surrounding community.

\section{Conclusion}

The results of this research can be concluded that there is a significant influence between the pedagogic competence on social competence and personality of the student PPG SM-3T Universitas Negeri Padang with the value of the count greater than T table $(2.132>1.960)$. This means that if the pedagogic competence of PPG SM-3T students is high, it will also increase the social competence and personality of PPG SM-3T students.

Although the results of this study proved that the professional competency improvement of the students was not followed by the increase of social competence and its personality with the value of $\mathrm{T}$ count smaller than the table $\mathrm{T}$ value $(0.290<1.960)$. This needs to get the attention of maintainers 
especially dormitory managers in the form of activities so as to be able to make high pedagogic competence and professional competence of students, the better also the social competence and personality.

The establishment of the competency of teachers is not separated from the philosophy of living, the values that develop in the place of teachers are then based on the results of the research advice that authors give PPG students SM-3T the next generation to improve competence Social and personality in the form of interactions with pupils, parents, associates and communities in the form of social activity, public visits and acting and behave in accordance with legal and social norms. To improve pedagogic and professional competence through training, seminars and workshops. To the manager of PPG SM-3T, State University of Padang can create an integrated program or curriculum in workshop for the development of PPG student Softskill SM-3T of Universitas negeri padang.

\section{References}

Anwar. (2004). Teacher competence in national education policy. Jakarta: Balai Pustaka

Cooper, (1984). Research business Translations 1 and 2. Jakarta: PT. Erlangga

Department of National Education. (2004). "Teacher Performance assessment Tool development". Jakarta: Dikjen Dikti, section of Project P2TK.

Feralys Novauli M. (2015). Master's competence in improving achievement in the state Junior high School in Banda Aceh. University of Syiah Kuala graduate Program

Irianto. (2015). Pengaruh Kompetensi Pedagogik, Profesional, Kepribadian dan Sosial Yang Dimiliki Dosen Terhadap Hasil Belajar Mahasiswa.

Mulyasa. (2012). Standar Kompetensi dan Sertifikasi Guru. Bandung: PT. Remaja Rosda Karya.

Peraturan Pemerintah Nomor 19 Tahun 2005 tentang Standar Nasional Pendidikan.

Permendiknas Nomor. 16 tahun 2007 tentang Standar Kompetensi Guru.

Prasetyo, Bambang. (2012). Metode Penelitian Kuantitatif. Jakarta: Rajawali Pers.

Sagala, Syaiful. (2011). Kemampuan Profesional Guru dan Tenaga kependidikan. Bandung: Alfabeta.

Undang-undang Republik Indonesia No. 14 Tahun 2005, Tentang Guru dan Dosen. Restindo Mediatama: Jakarta.

Uno, Hamzah. (2008). Profesi Kependidikan. Jakarta: Bumi Aksara.

Usman, Uzer, Moh. (2005). Menjadi Guru Profesional. Bandung: PT Remaja Rosdakarya. 